Journal of

Food and Nutrition

\title{
Investigation and Measurement of Some Mineral and Vitamins in Eggplant Fruit Calyx, and the Possibility of Being Used As Food Supplements and Alternative Medicine
}

\section{Khuloud Al Nachar*, Jameela Hasian, Racha Al Khatib}

Department of phytochemistry and Pharmacology, Faculty of pharmacy, Damascus university, Damascus city, syrian arab republic

*Corresponding author: Khuloud Al Nachar, Department of phytochemistry and Pharmacology, Faculty of pharmacy, Damascus university, Damascus city, syrian arab republic, E-mail: kholudalbeak@gmail.com

Received Date: June 11, 2019 Accepted Date: July 27, 2019 Published Date: July 29, 2019

Citation: Khuloud Al Nachar (2019) Investigation and Measurement of Some Mineral and Vitamins in Eggplant Fruit Calyx, and the Possibility of Being Used As Food Supplements and Alternative Medicine. J Food Nutr 5: 1-10.

\begin{abstract}
Food supplements are Plenty present in medicinal markets and have taken a great importance as they compensate for many of the minerals and vitamins lacking in human body, but most of them rely on introducing a chemicals substances in there composition without making an attention to their representation or its harmful effects in the body, this research has been interested in this regard and studied the components of eggplant calyx (cones) by confirming the existence of some minerals and vitamins with the identification of values and calibrated It, all these results has been compared with previous studies of these elements in edible part of the eggplant with mentioned of the daily recommended intake and the value of minerals and vitamins was greater than that in the edible part. So this study show the importance of these minerals and vitamins and link their presence with each other in influencing the health of the body and how it could protect it from certain diseases. Hence, we can say that this neglected and damaged eggplant calyx in our system Food is a natural and balanced food supplements, therefore this discovery will be important in the manufacture of dietary supplements.

keywords: Eggplant fruit calyx, Magnesium, Calcium, Vitamin C, Zinc
\end{abstract}

C2019 The Authors. Published by the JScholar under the terms of the Creative Commons Attribution License http://creativecommons.org/licenses/ by/3.0/, which permits unrestricted use, provided the original author and source are credited. 


\section{Introduction}

Eggplant (Solanum melongena L.), is a vegetable crop, economically important, consumed widely in Syria. Its native is related to the South East Asian region and was domesticated over 4000 years ago [1].

Many studies have been proved the effectiveness of fruit in the treatment of many diseases such as diabetes, gonorrhea, cholera, bronchitis, dyspnea, dysentery, debilitation and treatment of hemorrhoids thus, this extracts were either completely effective treatment or effective adjuvant treatment $[2,3]$.

Eggplant is low in calories and has various macroand micro-minerals, which are beneficial for human health [4].

These minerals have an important effect on human body such as the production of protein and fatty acids, supporting the immunity system and regulating blood sugar. However, the body does not get any benefit from some of the minerals found if the ratios of other minerals excess, for example increase zinc inhibits the absorption of magnesium and manganese, and cause the lack of copper and cause a less absorption of iron in the body [5].In addition, vitamin B5 and vitamin $\mathrm{C}$ are crucial to human nutrition, particularly, in the inflammation resistance [6].

Today, more than 2 billion people in the world are estimated to be deficient in key minerals, particularly, iron and zinc. Most of these people live in low income countries and are typically deficient in more than one micronutrient [7].

Although there are a few studies describing the mineral content in eggplant fruit [8], there is no information about the mineral content in eggplant calyx.

Hence, the present investigation was undertaken to detect and calibrate: calcium, manganese, magnesium, zinc, iron, copper, phosphorus, potassium, sodium, vitamin $\mathrm{C}$ and vitamin B5 ineligible part of eggplant and its effect on various organs and functions in the body.

\section{Materials and Methods of Research}

\section{Chemical reagents}

All the reagents used were analytical grade and obtained from Panreac, Spain.

\section{Plant materials}

Eggplants (Solanum melongena) were purchased from local markets in Damascus. The fruit calyx were obtained, dried, and stored away from moisture.

\section{Moisture content determination [9]}

$5 \mathrm{~g}$ of cones powder is taken in a petri dish.

- $\quad$ is then calculated : weight after drying - weight before drying X 100\Weight problem

Dry matter $=100-$ Humidity

\section{Determination of ash content $[10]$}

Ash is the inorganic residue remaining after the water and organic matter have been removed by heating in the presence of oxidizing agents, which provides a measure of the total amount of minerals within a food. Analytical techniques for providing information about the total mineral content are based on the fact that the minerals (the analyte) can be distinguished from all the other components (the matrix) within a food in some measurable way. The most widely used methods are based on the fact that minerals are not destroyed by heating, and that they have a low volatility compared to other food components. The three main types of analytical procedure used to determine the ash content of foods are based on this principle: dry ashing, wet ashing and low temperature plasma dry ashing. The method chosen for a particular analysis depends on the reason for carrying out the analysis, the type of food analyzed and the equipment available. Ashing may also be used as the first step in preparing samples for analysis of specific minerals, by atomic spectroscopy or the various traditional methods.

\section{Dry Ashing}

Dry ashing procedures use a high temperature muffle furnace capable of maintaining temperatures of between 500 and $600{ }^{\circ} \mathrm{C}$. Water and other volatile materials are vaporized and organic substances are burned in the presence of the oxygen in air to $\mathrm{CO}_{2}, \mathrm{H}_{2} \mathrm{O}$ and $\mathrm{N}_{2}$. Most minerals are converted to oxides, sulfates, phosphates, chlorides or silicates. Although most minerals have fairly low volatility at these high temperatures, some are volatile and may be partially lost, e.g., iron, lead and mercury. If an analysis is being carried out to determine the concentration of one of these substances then it is advisable to use an alternative ashing method that uses lower temperatures. 
The food sample is weighed before and after ashing to determine the concentration of ash present. The ash content can be expressed on either a dry or wet basis:

$\% \mathrm{Ash}_{\mathrm{s}}(\mathrm{dry}$ basis $)=\frac{\mathrm{MI}_{\mathrm{AHH}}}{\mathrm{MI}_{\mathrm{DFY}}} \times 100$

Ashes: $5 \mathrm{~g}$ of eggplant cones powder is taken and placed in a porcelain jar and then placed in a $550^{\circ} \mathrm{C}$ incineration oven for 2 hours. Weight after incineration the weight of the empty jar X100 \Weight problem Preparation of new samples from the ash sample: Preparation of precipitation from ash sample 100/5 ml: Take $5 \mathrm{~g}$ of ashes in a $100 \mathrm{ml}$ in flask $\rightarrow$ add $5 \mathrm{ml} \mathrm{HCL} \mathrm{(25 \% ) \rightarrow add}$ distilled water to $50 \mathrm{~mL} \rightarrow$ heat for less than $100^{\circ} \mathrm{C} \rightarrow$ refrigerate $\rightarrow$ Complete with the distilled water to the mark $\rightarrow$ filter.

The result filter is ready for metallurgical analysis

\section{Determination of mineral content [10]}

\section{Phosphorus}

The spectrophotometer is measured at a wavelength of $436 \mathrm{~nm}$ using an ammonium molibidate detector and the color intensity (yellow color) is measured with a standard series of phosphorus (KH2PO4)

Note: (Initial dilution is extended ten times to fit the concentration with the standard series)

\section{Sodium and potassium}

The electrode is measured by the flame of the electrolytes by blowing bonat/ air Standard series of $25 \% \mathrm{NaCl}$. and reading each metal along a specific wave by comparing it with a standard series and each series starting at $0.5 \mathrm{ppm}$ and ending with $5 \mathrm{ppm}$

Note: (Initial expansion was extended ten times to fit the standard deviation)

\section{Iron and zinc}

With an atomic absorption device with a standard series, using a gas (acetylene/air) With the use of measuring bulb

\section{Vitamin B5 and vitamin c}

The proportion of vitamin B5 is determined by the HPLC according to the approved reference
Column: Vinyl column (SB-Vinyl) with dimensions of $5 \mathrm{Mi}-$ cron. $25 \mathrm{~cm} \times 4.6 \mathrm{~mm}$

Wave length: $280 \mathrm{~nm}$

Flow of the mobile phase: $1 \mathrm{ml} / \mathrm{min}$

Injection quantity: $20 \mu \mathrm{L}$

Mobile phase A: Water: Methanol: Snow vinegar: Tri-ethylamine (97: 2: 1: 0.12)

With 100 mg Sulfonic Acid

Mobile phase B: Water: Methanol: Ice Acetic Acid: Tri ethylamine (27: 72: 1: 0.12)

B5

We carefully weigh $10 \mathrm{mg}$ of B5 into a $100 \mathrm{ml}$ flask.

Add approximately $70 \mathrm{ml}$ of the extension solution (monosodium phosphate M.0.05 at $\mathrm{pH}=6.8$

To the former volumetric flask $100 \mathrm{~mL}$, then put the volumetric flask on the ultrasonic wave bath for five minutes

We complete the signal by the extension solution and then take the previous mixture $4 \mathrm{ml}$ into a $10 \mathrm{~mL}$ volumetric flask

We even complete the signal by the extension solution

Vitamin C is neutralized by HPLC according to House Method.

The sample transporter phase is composed of acidic potassium phosphate of $50 \mathrm{mM}$ and methanol.

The sample is methanol or electrolytic water. Wave length nm254

\section{Results and Discussion}

The analysis of fruits calyx revealed low moisture content (10.6\%), that makes them less susceptible to infection by micro-organisms. High level of ash content have also been reported (11.6\%).

Analyses of the mineral showed that the contents of minerals were moderate and sufficient for the daily need (table 1). 


\begin{tabular}{|l|l|l|l|}
\hline Minerals and vitamins & $\begin{array}{l}\text { Daily recommended in- } \\
\text { take }(\mathbf{m g})\end{array}$ & $\begin{array}{l}\text { Percentage of ingredients } \\
\text { in eggplant cones (mg } \\
/ \mathbf{1 0 0 g})\end{array}$ & $\begin{array}{l}\text { Percentage of ingredients } \\
\text { in edible part(mg /100g) }\end{array}$ \\
\hline Phosphorus & 1000 & 350 & 47 \\
\hline Magnesium & 410 & 180 & 15 \\
\hline Potassium & 3400 & 1400 & 2 \\
\hline Sodium & 2300 & 100 & 3 \\
\hline iron & 15 & 4.7 & 0.38 \\
\hline Zinc & 11 & 1 & 0.22 \\
\hline Manganese & $1.8-2.3$ & 0.68 & 18 \\
\hline Calcium & 1300 & 450 & 0.12 \\
\hline Copper & 0.9 & 0.46 & \\
\hline Vitamin B5 & 5 & 7,3 & 12 \\
\hline Vitamin C & 75 & 45 & \\
\hline
\end{tabular}

Table 1: Comparison between Minerals and vitamins in edible part of eggplant [11], daily recommended intakes and Percentage of ingredients in eggplant cones

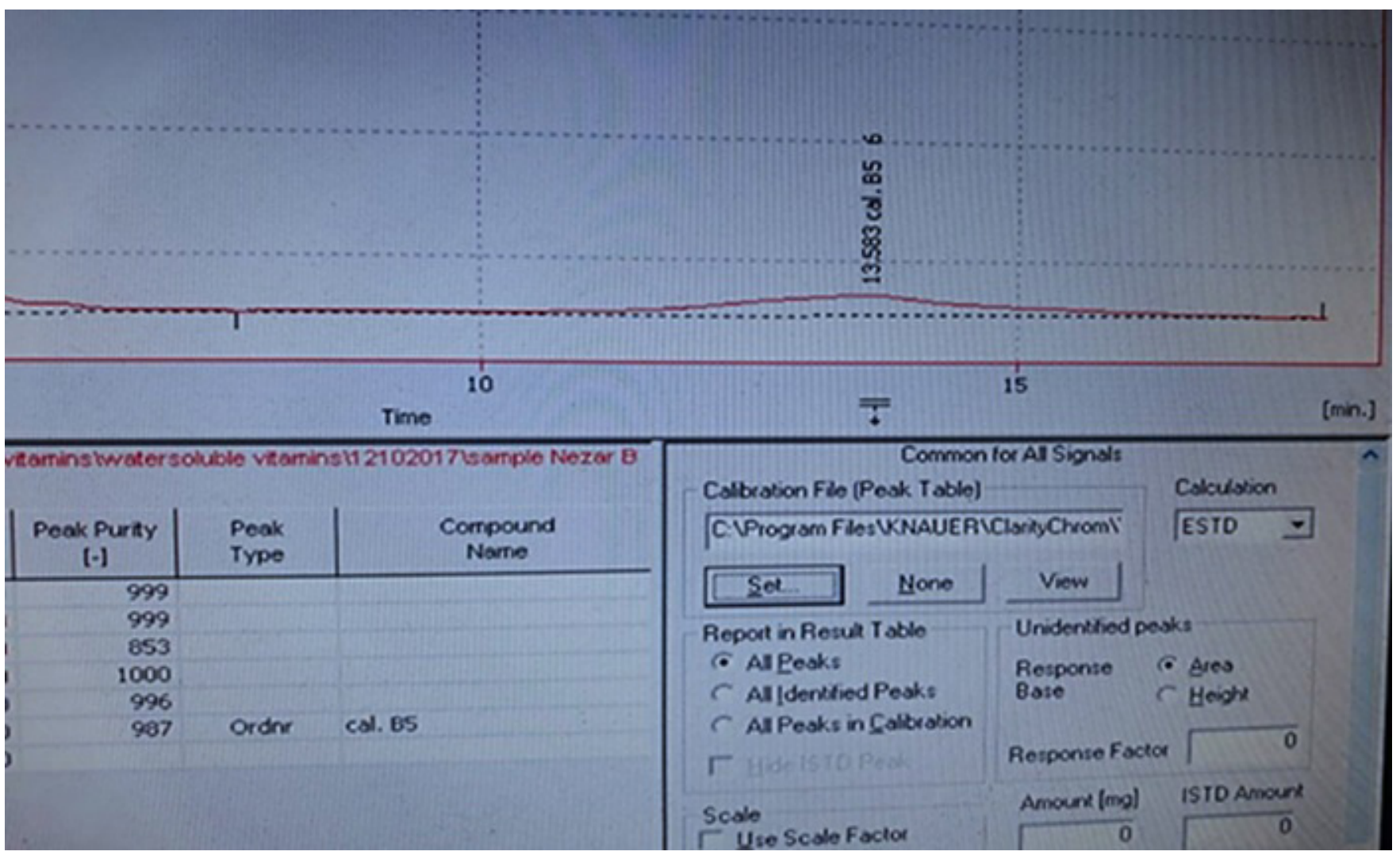

Figure 1: Graphical curve of vitamin b5 


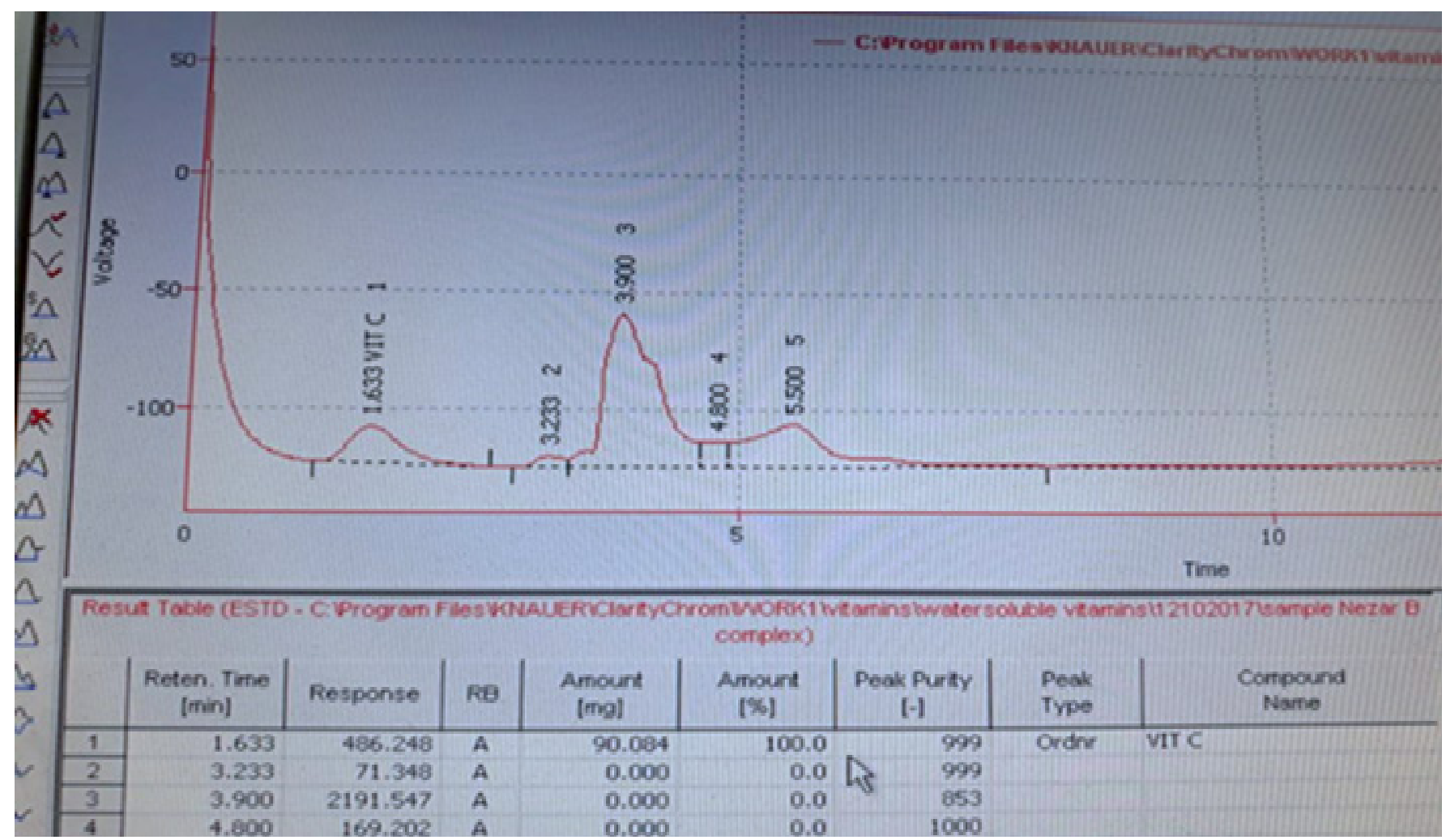

Figure 2: Graphical curve of vitamin c

\section{Discussion}

Magnesium (Mg) level was $180 \mathrm{mg} / 100$ g compared to $15 \mathrm{mg} / 100 \mathrm{~g}$ in eatable part. Since the daily recommended intakes is $410 \mathrm{mg}$. [12], the amount of magnesium is important, especially for protein [13] and of DNA [14] manufacture, removes toxic ammonia from the body, supporting the immune system, regulate blood sugar because it promotes the secretion of insulin [15], reduces anxiety, improves the quality of sleep and mood because serotonin depends on magnesium [16], relieves asthma attacks [17] and helps to support the muscle system and bones to protected from muscle spasm [18].

manganese with a concentration of $0.68 \mathrm{mg} / 100 \mathrm{~g}$ and a daily recommended intakes of 2.3-1.8 $\mathrm{Mg}$ [19], the amount present is equivalent to one third of the allowable amount, which is important for the nervous system, helps in protein and amino acids digestion [20], supports bone mineral density with (calcium, zinc and copper) [21], play a role in regulating blood sugar because it is concentrated in the pancreas and it is involved in insulin production [22,23] a blood vessel expander that reduces the risk of stroke $[24,25]$ and necessary for brain functions through Its antioxidant activity [20].

Zinc level was of $1 \mathrm{mg} / 100 \mathrm{mg}$ versus 0,22 mg / 100g in the edible part of the previous studies The daily recommended intakes is $11 \mathrm{mg}$ [19], which means that the amount is moderated ,zinc is important for protein, nucleic acids and DNA production, Cell regeneration Where it prevents degradation of The blood vessels inner walls endothelium keeping the Arteries and veins healthy , an antioxidant properties [26], and maintain the integrity of the immune system so it prevents cancers development, reduces lungs inflammation and inhibits viruses [27], also pancreas contains amount of zinc so any deficiency in it well cause a lack in Insulin secretion [28].

It is obvious that zinc quantity is good so it does not affect the amount of magnesium and manganese because the zinc increases their lacking.

Therefore the zinc amount is good for body elements balance because its increase makes a copper lack and a decrease in iron absorption so it is better for anemia patient to take (iron + copper + folic + vitamin C) [29].

Iron (Fe) level was $4.7 \mathrm{mg} / 100 \mathrm{~g}$ compared with $0.38 \mathrm{mg} / 100 \mathrm{~g}$ from eatable part. The daily recommended intakes is $15 \mathrm{mg}$ [19], one third of the resulting quantity is equivalent to one third of the daily recommended intake, makes it very important in Enzymes function, help absorbing oxygen, convert blood sugar into energy, and protect body from anemia [30], However. Body does not get any benefit from iron found in food or medicine if the 
person suffers from deficiency of copper [31] or vitamin C [32] therefore the calibration has been done also on copper and vita$\min \mathrm{C}$.

Copper (Cu) level was $0.46 \mathrm{mg} / 100 \mathrm{~g}$ compared with $0.12 \mathrm{mg}$ / $100 \mathrm{~g}$ from the eatable part of the previous studies. Since the daily recommended intakes is $0.9 \mathrm{mg}$ [19], therefore the resulting quantity is a half of the quantity required. This is very important and useful. Because Copper helps to form body collagen [33], iron absorption [34]. Metabolism [34], energy production [35], red blood cells formation [36], maintain bones health [37], prevent cardiovascular disease [38], prove immune function, and has an antioxidant activity [39].

Vitamin C level was $45 \mathrm{mg}$ / $100 \mathrm{~g}$ vs $12 \mathrm{mg}$ / $100 \mathrm{~g}$ in the eatable part of the previous studies Since The daily recommended intakes were $90 \mathrm{mg}$ [40] This is very important because it helps in Bones, skin and blood vessels composition and maintenance [41], has an important role in a number of physical functions including the collagen [42], keratin [43], and some neurotransmitters [42], production, promotes iron absorption [44], its antioxidant activity may reduce the risk of some cancer types [45], prevent acute respiratory infections (Moser and Chun, 2016),protect against cardiovascular disease [46], and has beneficial effect on diabetic patients as it reduces the risk of kidney, eye and nerve deterioration [41].

In the field of bone health, these elements have an important effect to increasing density and protection, as mentioned earlier, but this importance remains incomplete without the effect of calcium and phosphorus.

With calcium calibrations, the concentration was $450 \mathrm{mg} / 100 \mathrm{~g}$ versus $18 \mathrm{mg} / 100 \mathrm{~g}$ in the treated part of previous studies since the daily recommended intakes are $1300 \mathrm{mg}$ [47], the result of concentration is very substantial for body's need, such as it is an adjunct to many enzymes [48], plays a key role in natural blood clotting [49], and it helps skin by regulating the color of it [50] and allows to protect itself. help reduce the risk of colorectal cancer [51], About 99\% of it found in bones and teeth [52] It is essential for bone development, growth and maintenance [53], and the healthy communication between the brain and other parts of the human body in addition to it regulates muscle contraction, including myocardium [54], Phosphorus (P) concentration was $350 \mathrm{mg} / 100 \mathrm{~g}$ compared with $47 \mathrm{mg} / 100 \mathrm{~g}$ in eatable part in the previous studies. Daily recommended intakes are $700 \mathrm{mg}$ [55], and here we find that the amount contained in eggplant cones equal to half the amount appropriate to the body need.
Phosphorus is an important element as it interacts with calcium to strength, build bones and muscles [56], work to strength the nerves and increase men's sexual ability [57], has a beneficial effect for hair healthy growth and protect it against fallout and Damage [58] and it helps cells to control proteins rate within the body, also the excess amount of it causes in calcium and magnesium absorption [59]. Therefore, its concentration in the extract is beneficial without causing damage to the level of calcium and manganese. Thus, the useful minerals for bone health in this summary are fully and balanced.

To confirm the benefit of nutritional of the extract on heart and blood vessels, this study includes comparing sodium and potassium value.

Sodium (Na) concentration is $100 \mathrm{mg} / 100 \mathrm{~g}$ versus $3 \mathrm{mg} / 100 \mathrm{~g}$ in eatable part in previous study. Daily recommended intakes are $2300 \mathrm{mg}[60,61]$ Since these salts can spoil the internal epithelial layer of the micro vascular, this increases the problem of thrombosis and affects the immune system and increases it leads to atherosclerosis [62], sodium is responsible for sending signals through the nerves and enables the muscles to contract, the balance between the two can help the heart and blood vessels and the amount needed for it (4700 mg potassium/800 mg sodium) [2] or 14/1 This helps to balance fluid body [63] and this is achieved in Eggplant cones where we find its importance clear by its role in maintaining the fluid of volume of intracellular and cross-membrane electrochemical gradients. The FDA has agreed on the following health claim: "Dietary foods are containing a good potassium source containing low sodium content may reduce the risk of hypertension and stroke Cerebral [64]. And observational studies suggest that potassium is associated with control of blood glucose and type 2 diabetes [65].

In addition, it indicates that increased potassium consumption from fruits and vegetables is associated with increased bone mineral density [66], Here we see that potassium has an important effect on bone health, heart patients [67], and diabetes [68].

Vitamin B5 (ban tonic acid) was calibrated as a result of the calibration of $7.3 \mathrm{mg} / 100 \mathrm{~g}$. The daily recommended intakes are 5 mg [69] because it enhances the health of the skin, hair, eyes [70] and liver and assists in the formation of red blood cells and the conversion of food into glucose [71]. Studies suggest that taking vitamin B-5 can help lower cholesterol and triglyceride levels in the blood [72], its decrease causes respiratory infections [73] and increases insulin sensitivity [74]. 


\section{Conclusion}

This study revealed that eggplant calyx extract contained minerals and vitamins with concentrations higher than the edible part, which is generally important and useful food for cardiovascular and diabetics patients and has a significant role in maintaining the health of bones, muscles and alleviate the inflammation with good support for the role of immunity of the body and some studies prove that the combination of the following elements (phosphorus, potassium and vitamin C) in there appropriate amounts for the body, they well calms the pain. eggplant cone has very important minerals which billions of people are estimated to be deficient and can be a alternative to this deficiency.

We hope that those who are interested in health benefit from the eggplant cones, do not expose them to damage their richness with beneficial nutritional supplements to the human body.

\section{Reference}

1) Arivalagan M, Bhardwaj R, Gangopadhyay K.K, et al. (2013) Mineral composition and their genetic variability analysis in eggplant (Solanum melongena L.) germplasm. Journal of Applied Botany and Food Quality 86: 99 - 103.

2) Bello SO, Muhammed BY, Gammaniel KS, Abdu-Ayugel KS, Ahmed H, et al. (2005) Preliminary evaluation of the toxicity and some Pharmacological properties of Aqueous crude extract of Solanum melongena. Research Journal of Agricultural and Biological Sciences $1: 1-9$.

3) Gill LS (1992) Ethno medical uses of plants in Nigeria. University of Benin Benin, Nigeria 215.

4) Taher D, Solberg S, Prohens J, Chou Y, et al. (2017) World Vegetable Center Eggplant Collection: Origin, Composition, Seed Dissemination and Utilization in Breeding. Front Plant Sci 8:1484.

5) David L. Watts DC (1988) The Nutritional Relationships of Zinc Journal of Orthomolecular Medicine 3.

6) Wenting He, Shengfeng Hu, Xialin Du, Qian Wen, et al. (2018) Vitamin B5 Reduces Bacterial Growth via Regulating Innate Immunity and Adaptive Immunity in Mice Infected with Mycobacterium tuberculosis, Front Immunol 9: 365.

7) WHO/UNHCR (2005) Multiple Vitamin and Mineral Supplements for Pregnant and lactating women, and Children aged 6 to 59 Months (WHO/NHD).

8) Russo MV (1996) Cultural Methods and Mineral Content of Eggplant (Solanum melongena) Fruit, Journal of the Science of Food and Agriculture 71:119-123

9) Fao (1980) the state of food and agriculture no .12.

10) AOAC (1990) Official methods of the Association of Official AnalyticalChemists. 15th Edition. Washington, DC, USA.

11) Gopalan C, Rama Sastri BV and Balasubramanian S (2007) Nutritive Value of Indian Foods, National Institute of Nutrition (NIN), ICMR. Hyderabad, Research Journal of Agricultural and Biological Sciences, 1: 1-9.

12) Institute of Medicine (IOM) (1997) Food and Nutrition Board. Dietary Reference Intakes: Calcium, Phosphorus, 
Magnesium, Vitamin D and Fluoride external link disclaimer. Washington, DC: National Academy.

13) Jewett MC, Miller ML, Chen Y, and Swartz JR (2009) Continued Protein Synthesis at Low [ATP] and [GTP] Enables Cell Adaptation during Energy Limitation. J Bacteriol 191:10831091.

14) De Baaij JH, Hoenderop JG, Bindels RJ (2015) Magnesium in man: implications for health and disease." Physiol Rev 95:1-46.

15) Kostov K (2019) Effects of Magnesium Deficiency on Mechanisms of Insulin Resistance in Type 2 Diabetes: Focusing on the Processes of Insulin Secretion and Signaling Int J Mol Sci. Mar; 20: 1351.

16) Eby GA, Eby KL and Murk H (2011) Magnesium and major depression" University of Adelaide.

17) Shrader WA (2004) Short and long term treatment of asthma with intravenous nutrients" Nutr J 3: 6.

18) Bilbey DL, Prabhakaran VM (1996) Muscle cramps and magnesium deficiency: case reports. Can Fam Physician 42:1348-1351.

19) Institute of Medicine US (2001) (IOM) Food and Nutrition Board. Dietary Reference Intakes for Vitamin A, Vitamin K, Arsenic, Boron, Chromium, Copper, Iodine, Iron, Manganese, Molybdenum, Nickel, Silicon, Vanadium, and Zinc: a Report of the Panel on Micronutrients External link disclaimer. Washington, DC: National Academy.

20) Chen P, Bornhorst J, Aschner M (2018) Manganese metabolism in humans Front Biosci 23:1655-1679.

21) Leffler CT, Philippi AF, Leffler SG, Mosure JC, Kim PD (1999) Glucosamine, chondroitin, and manganese ascorbate for the degenerative joint disease of the knee or low back: a randomized, double-blind, placebo-controlled pilot study. Mil Med 164:85- 91 .

22) Kazi TG, Afridi HI, Kazi N, Jamali MK, Arain MB, Jalbani N, Kandhro GA (2008) Copper, chromium, manganese, iron, nickel, and zinc levels in biological samples of diabetes mellitus patients. Biol Trace Elem Res 1221:1-18.

23) Koh E S, Kim S J, Yoon HE, Chung GH, Chung S, et al.
(2014) Association of blood manganese level with diabetes and renal dysfunction: a cross-sectionall study of the Korean general population" BMC Endocr Disord 14: 24.

24) Korc M, Brannon PM (1988) Regulation of Pancreatic Exocrine Function by Manganese, Departments of Internal Medicine and Nutrition and Food Science University of Arizona Tucson USA REW.

25) Lee SH, Jouihan HA, Cooksey RC, et al. (2013) Manganese supplementation protects against diet-induced diabetes in wild type mice by enhancing insulin secretion. Endocrinology154:1029-1038.

26) Osredkar J, Sustar N (2011) Copper and Zinc, Biological Role and Significance of Copper/Zinc Imbalance Journal of Clinical Toxicology 2161-0495.

27) Pae M, Meydani SN, Wu D (2012) The Role of Nutrition in Enhancing Immunity in Aging. Aging Dis. 3: 91-129.

28) Fukunaka A, Fujitani Y (2018) Role of Zinc Homeostasis in the Pathogenesis of Diabetes and Obesity" Int J Mol Sci. 19: 476.

29) Khoshfetrat MR, Mortazavi S, Neyestani T, Mahmoodi MR, Zerafati-Shore N, and Mohammadi-Nasrabadi F (2014) Iron and Vitamin C Co-Supplementation Increased Serum Vitamin C Without Adverse Effect on Zinc Level in Iron Deficient Female Youth" Int J Prev Med 5: 1037-1044.

30) Dr. Gupta CP (2014) Role of Iron (Fe) in Body" IOSR Journal of Applied Chemistry (IOSR-JAC) 7: 2278-5736.

31) Reeves PG, DeMars LC (2006) Signs of iron deficiency in copper-deficient rats are not affected by iron supplements administered by diet or by injection. J NutrBiochem 17:635-42.

32) Kuroyanagi $m$, shimamura e, kim m, arakawa n, fujiwara y, otsuka m (2002) Effects of L-Ascorbic Acid on Lysyl Oxidase in the Formation of Collagen Cross-links. Jstage. 66: 20772082.

33) Reeves PG, DeMars LC (2004) Copper deficiency reduces iron absorption and biological half-life in male rats. J Nutr 134:1953-1957.

34) chan WY, Owen M, Renner T MD (1980) The Role of Copper in Iron Metabolism. Institute for Clinical Science 10, No. 
4.

35) Hordyjewska A, Popiołek L, and Kocot J (2014) The many "faces" of copper in medicine and treatment Biometals 27: 611-621.

36) Cartwright ge, gubler jc, and wintrobe mm (1958) the role of copper in erythropoiesis. National academies.

37) Pepa DG, Brandi LM (2016) Microelements for bone boost: the last but not the least. Clin Cases Miner Bone Metab 13: 181-185.

38) Kang YJ (2010) Copper and homocysteine in cardiovascular diseases. Pharmacology \& Therapeutics $129: 321-331$.

39) Vignesh SK, Deepe, Jr. SG (2017) Metallothioneins: Emerging Modulators in Immunity and Infection.Int J Mol Sci 18: 2197.

40) Institute of Medicine (2000) Food and Nutrition Board. Dietary Reference Intakes for Vitamin C, Vitamin E, Selenium, and Carotenoidsexternal link disclaimer. Washington, DC: National Academy Press.

41) Chambial S, Dwivedi S, Shukla KK, John JP, and Sharma P (2013) Vitamin C in Disease Prevention and Cure: An Overview Indian J Clin Biochem 28: 314-328.

42) Maxfield L, Crane S J (2019) Vitamin C Deficiency (Scurvy) Stat Pearls Publishing.

43) Cook JD, Reddy MB (2001) Effect of ascorbic acid intake on nonheme-iron absorption from a complete diet The American Journal of Clinical Nutrition 73:93-98.

44) Vissers CMM and Das BA (2018) Potential Mechanisms of Action for Vitamin C in Cancer: Reviewing the Evidence Front Physiol 9: 809.

45) Hemila H, Douglas RM (1999) Vitamin C and acute respiratory infections. Int J Tuberc Lung Dis. Sep 3:756-761.

46) Moser A.M, and Chun K.O (2016) Vitamin C and Heart Health: A Review Based on Findings from Epidemiologic Studies Int J Mol Sci.17: 1328.

47) Institute of Medicine (US) (2011) Committee to Review Dietary Reference Intakes for Vitamin D and Calcium; Ross AC, Taylor CL, Yaktine AL, et al., (eds)Washington (DC): National Academies Press (US); Dietary Reference Intakes for Calcium and Vitamin D. Overview of Calcium

48) Mellgren L.R (1987) Calcium-dependent proteases: an enzyme system active at cellular membranes? FASEBJ 1: 110115.

49) Palta S, Sarao R, Palta A (2014) Overview of the coagulation system. Indian J Anaesth 58: 515-523.

50) Mostafa ZW and Hegazy AR (2015) Vitamin D and the skin: Focus on a complex relationship: A review Journal of Advanced Research Volume 6: 793-804.

51) Terry P, Baron JA, Bergkvist L, Holmberg L (2002) Dietary calcium and vitamin $\mathrm{D}$ intake and risk of colorectal cancer: A prospective cohort study in women. Nutrition and Cancer 43:39-46.

52) Institute of Medicine (US) (2011) Committee to Review Dietary Reference Intakes for Vitamin D and Calcium; Editors: A Catharine Ross, Christine L Taylor, Ann L Yaktine, and Heather B Del Valle. Dietary Reference Intakes for Calcium and Vitamin D Washington (DC): National Academies Press (US).

53) Hadjidakis JD, and Androulakis II (2007) bone remodeling nyas.

54) Nayler WG (1981) The role of calcium in the ischemic myocardium. Am J Pathol 102:262-270.

55) Food and Nutrition Board FNB, Institute of Medicine IOM (1997) Phosphorus. Dietary Reference Intakes: Calcium, Phosphorus, Magnesium, Vitamin D, and Fluoride. Washington D.C. National Academy Press 146-189.

56) Beto A.J (2015) The Role of Calcium in Human Aging" Clin Nutr Res 4: 1- 8 .

57) Shridharani AN and Brant WO (2016) The treatment of erectile dysfunction in patients with neurogenic disease. TranslAndrol Urol 5: 88-101.

58) Abdolzadeh A, Wang X, Veneklaas E.J, and Lambers $H$ (2010) Effects of phosphorus supply on growth, phosphate concentration and cluster-root formation in three Lupinus species" Ann Bot 105: 365-374.

59) Paunier L (1992) Effect of magnesium on phosphorus and calcium metabolism." Monatsschr Kinderheilkd 140:17-20.

60) IOM (2004) Dietary Reference Intakes: Water, Potassi- 
um, Sodium, Chloride, and Sulfate. Panel on Dietary Reference Intakes for Electrolytes and Water Standing Committee on the Scientific Evaluation of Dietary Reference Intakes national academy of science engineering medicine.

61) Usda Dietary Guidelines For Americans Book 2015 2020 Eighth

62) Edwards DG and Farquhar WB (2015) Vascular Effects of Dietary Salt" CurrOpinNephrolHypertens. 24: 8-13.

63) Harvard Heart Letter (2009- 2019) Potassium and sodium out of balance. Harvard health publishing.

64) U.S. Food and Drug Administration (FDA) (2016) Food Labeling: Revision of the Nutrition and Supplement Facts Labels. external link disclaimer Federal Register 81: 33894-33895.

65) Chatterjee R, Slentz C, Davenport CA, Johnson J, Lin PH, Muehlbauer M (2017) Effects of potassium supplements on glucose metabolism in African Americans with prediabetes: a pilot trial. Am J Clin Nutr106:1431-1438.

66) Hanley DA, and Whiting SJ (2013) Does a high dietary acid content cause bone loss, and can bone loss be prevented with an alkaline diet? J Clin Densitom 16:420-425.

67) Weaver CM (2013) Potassium and Health Adv Nutr. 4: 368-377.

68) Chatterjee R, Yeh HC, Edelman D, and Brancati F (2011) Potassium and risk of Type 2 diabetes"(H SS PUPLIC ACCESS) Expert Rev Endocrinol Metab 6: 665-672.

69) Institute of Medicine IOM (US) (1998) Standing Committee on the Scientific Evaluation of Dietary Reference Intakes and its Panel on Folate, Other B Vitamins, and Choline. Dietary Reference Intakes for Thiamin, Riboflavin, Niacin, Vitamin B6, Folate, Vitamin B12, Pantothenic Acid, Biotin, and Choline Washington (DC): National Academies Press (US); ISBN-10: 0-309-06411-2ISBN-13: 978-0-309-06411-8.

70) Kennedy OD (2016) B Vitamins and the Brain: Mechanisms, Dose and Efficacy-A Review Nutrients.; 8: 68.

71) Almohanna MH, Ahmed AA, Tsatalis PJ, and Tosti A (2019) The Role of Vitamins and Minerals in Hair Loss: A Review Dermatol Ther (Heidelb). 9: 51-70.
72) Kathiresan S, Melander O, Melander OM (2008) Six new loci associated with blood low-density lipoprotein cholesterol, high-density lipoprotein cholesterol or triglycerides in humans Nature Genetics 40, pages 189-197 Antoine Ménoret, Sanjeev Kumar, Anthony T. Vella (2012) Cytochrome b5 and Cytokeratin 17 Are Biomarkers in Bronchoalveolar Fluid Signifying Onset of Acute Lung Injury.

73) Hazelwood RL, bennett LL, Nelson MM (1956) Effect of pantothenic acid deficiency on insulin sensitivity and response to ACTH of intact and diabetic rats Endocrinology 58:427-434.

74) Harrison FE and May JM (2009) Vitamin C function in the brain: the vital role of the ascorbate transporter SVCT2. Free RadicBiol Med 46: 719-730.

Submit your manuscript to a JScholar journal and benefit from:

ฯ Convenient online submission

๑ Rigorous peer review

I Immediate publication on acceptance

I Open access: articles freely available online

I High visibility within the field

ब Better discount for your subsequent articles

Submit your manuscript at http://www.jscholaronline.org/submit-manuscript.php 